\title{
Slovak Whistleblowing Law after Revision - a Step Forward?
}

\author{
Peter Varga, Veronika Zoričáková ${ }^{1}$
}

https://doi.org/10.18778/8220-639-5.10

\section{Legal sources of whistleblowing in Slovakia}

The Slovak legal framework regulating whistleblower protection has been developed in recent years. The first legislation was drafted based on the resolution of the Government of the Slovak Republic on the draft measures to ensure compliance with the recommendations adopted by the OECD Working Group on Bribery in International Business Transactions for the Slovak Republic as part of Phase 3 of the evaluation.

\subsection{Development of Slovak legislation of whistleblower protection}

The first piece of legislation was also defined in the Programme Statement of the Government of the Slovak Republic for the years 2012-2016, which set the goal to strengthen the protection of whistleblowers, including by adopting new legislative measures. With regard to international conventions, the Slovak Republic ratified the Civil Law Convention on Corruption as a member state of the Council of Europe, the Criminal Law Convention on Corruption as a member state of the Council of Europe, the United Nations Convention against Corruption (UNCAC), and the (partly related to whistleblowing) Convention of the International Labour Organisation concerning Termination of Employment at the Initiative of the Employer No. 158 of the year 1982 .

The proposal was based on several international documents:

- Criminal Law Convention on Corruption; ${ }^{2}$

- Civil Law Convention on Corruption; ${ }^{3}$

1 Doc. JUDr. Peter Varga, PhD - Mgr. Veronika Zoričáková, PhD, Trnava University, Faculty of Law.

2 ETS No. 173, see Article 22: Protection of collaborators of justice and witnesses, https://www. coe.int/en/web/conventions/full-list/-/conventions/rms/090000168007f3f5?module=treaty-detail\&treatynum=173. accessed 01/09/2021.

3 ETS No. 174, see Article 9: Protection of employees, source: https://www.coe.int/en/web/conventions/full-list/-/conventions/rms/090000168007f3f6?module=treaty-detail\&treatynum=174 accessed 01/09/2021. 
- United Nations Convention against Corruption; ${ }^{4}$

- Recommendation CM/Rec(2014)7 of the Committee of Ministers to Member States on the protection of whistleblowers, ${ }^{5}$ which stipulated several principles addressed to the Member States with regard to drafting legislation as well as guidelines in the area of whistleblowing.

The Parliament adopted the first legislation protecting whistleblowers in 2014 (Act No. 307/2014 Coll. on certain measures related to the reporting of anti-social activities and on change and amendment of some laws, hereinafter 'the previous Act').

\subsection{Current legislation on whistleblower protection}

The previous Act was, however, relatively soon replaced by the current Act No. 54/2019 Coll. on the protection of whistleblowers of anti-social activities and on change and amendment of some laws (hereinafter 'the Act'), which completely replaced the previous regulation. The Act became effective as from 1 March 2019. The purpose for adopting the new Act was to strengthen the position of whistleblowers in criminal proceedings (e.g. granting them the right to propose and submit evidence and the right to be informed about the cessation or conditional cessation of criminal proceedings) by increasing their protection or establishing an independent state administration body with national competence to protect whistleblowers.

There is one general act protecting whistleblowers in the Slovak Republic, i.e. there are no specific sectoral acts that would cover specific areas of law. The Act applies to both the private and the public sector, as it covers whistleblower protection also with regard to public sector employees and other employees in the public sphere (Section $2(\mathrm{e})$ of the Act $)^{6}$.

\subsection{Anti-discrimination legislation in the context of whistleblower protection}

The Act No. 54/2019 Coll. extended the grounds for which discrimination is prohibited. The declared purpose of this measure was to protect employees against

4 See Article 33: Protection of reporting persons: source: https://www.unodc.org/documents/ treaties/UNCAC/Publications/Convention/08-50026_E.pdf, accessed 01/09/2021. See p. 33 of the document.

5 See the text https://search.coe.int/cm/Pages/result_details.aspx?Objectld=09000016805c5ea5, accessed 01/09/2021.

6 See A. Olšovská, V. Hrušovská, Whistleblowing na pracovisku - právna úprava, teória a prax na Slovensku - Whistleblowing at the workplace - legislation, theory and practice in Slovakia, [in:] Whistleblowing, J. Pichrt (ed.), Wolters Kluwer ČR, Prague 2013. 
unlawful actions from the employer. The Act No. 365/2004 Coll. on equal treatment in certain areas and on protection against discrimination and on amendments to certain acts (Anti-discrimination Act) enumerates the grounds on which discrimination is prohibited (the list of grounds is not closed). The list explicitly includes the ground of reporting a crime or other anti-social activity (Section 2(1) of the Anti-discrimination Act).

The application of the Anti-discrimination Act enhances the protection of whistleblowers due to reverse burden of proof that may be applied. The reverse burden of proof requires the defendant to prove that he/she has not infringed the principle of equal treatment if the plaintiff informs the court of facts from which it can reasonably be concluded that the principle of equal treatment has been infringed. The whistleblower as an applicant is firstly required to identify in the application the person alleged to have infringed the principle of equal treatment. The whistleblower should also provide the facts he/she is aware of that prove the defendant breached the equal treatment principle. Based on these facts, the court may decide that the burden of proof is on the defendant.

\subsection{The Labour Code in the context of whistleblower protection}

The Slovak Labour Code (Act No. 300/2001 Coll.) stipulates that the employer is obliged to treat employees in accordance with the principle of equal treatment established for the area of labour relations. The Labour Code enumerates the grounds for which discrimination is prohibited, but it refers to the Anti-discrimination Act, i.e. the Anti-discrimination Act must be applied as a specific act in addition to the Labour Code .

If a person would be discriminated in labour relations due to whistleblowing, it would be considered as unjustified sanction. The Anti-discrimination Act stipulates that "unjustified sanction" (Section $2 \mathrm{a}(8)$ of the Anti-discrimination Act) is an act or omission which is unfavourable and directly related to the person concerned and has direct connection with: (a) seeking legal protection against discrimination on his/her own behalf or on behalf of another person; or (b) giving a witness statement or explanation or participating in proceedings in matters related to the violation of the principle of equal treatment, (c) making a complaint alleging breach of the principle of equal treatment ${ }^{8}$.

7 See H. Barancová a kol., Zákonník práce. Komentár (Labour Code. Commentary), 2. edition, C. H. Beck, Bratislava 2019.

8 See: Debréceniová J., Antidiskriminačný zákon. Komentár. Občan a demokracia (Anti-discrimination law. Commentary. Citizen and Democracy), Bratislava 2008, pp. 85-89. 


\subsection{The Office for Whistleblower Protection}

One of the most important modifications of the whole whistleblowing process in the Slovak Republic was that the Act established a new Office for Whistleblower Protection (hereinafter the "Office"). The Act stipulates that the Office is an independent state administration body with nationwide competence, which protects the rights and legitimate interests of whistleblowers who notify anti-social activities (Section 13(1) of the Act). However, the Office started to fulfil its tasks only in September 2021, as the head of the Office was elected by the Parliament only in February 2021 (despite the Act being effective from 1 March 2019).

Among the general tasks of the Office are the general monitoring of compliance with the Act and the way the Act is applied. The Office for Whistleblower Protection has a competence in terms of protection of whistleblowers, e.g. it may suspend the effectiveness of an act affecting employment terms or working conditions of an employee made by the employer with a negative consequence to the employment of the whistleblower unless the employer persuades the Office that there is no connection between the act and the whistleblower's report (for more detail see further below). In addition, once an employee obtains the status of a whistleblower, the Office needs to grant its prior consent to every act affecting employment terms or working conditions with a negative impact on the employment, otherwise the act is invalid. The Office may also monitor whether the employer's internal CSR standards and internal verification process of reports are in compliance with the Act and may impose fines if these duties are not duly fulfilled. After the Office is fully established, it is expected to serve other functions in the area of providing advice and consultation in connection with the notification of anti-social activities, such as issue expert opinions and methodological guidelines in matters of whistleblower protection, provide to employers advice as well as practical training and education, and cooperate with other authorities in the Slovak Republic and with similar institutions and organizations of the European Union and other countries. The Office is going to cooperate with the Slovak National Centre for Human Rights ${ }^{9}$ and with non-governmental organizations in matters of whistleblower protection.

9 The Slovak National Centre for Human Rights is a national human rights institution (NHRI) established in the Slovak Republic. The Centre acts also as the only Slovak equality body. It performs a wide range of tasks in the area of human rights and fundamental freedoms and observance of the principle of equal treatment. While the old Act No. 307/2014 Coll. (effective until 28 February 2019) was in force, the Centre used to be obliged to regularly evaluate and publish legal documents, court decisions, certain provisions and other relevant information related to criminal social conduct and protection. 


\subsection{Future development of legislation in the Slovak Republic}

The Act has not been changed or amended yet. However, the EU Member States have an obligation to transpose the Directive 2019/1937 of the European Parliament and of the Council of 23 October 2019 on the protection of persons who report breaches of Union law ${ }^{10}$ by 17 December 2021, i.e. the Act is expected to be amended. As the draft of a new act that would transpose the Directive has not been prepared or even discussed yet, we are not aware whether an amendment or a completely new act will be adopted.

\section{Personal scope of whistleblower protection granted by the new Act}

The new Act provides the definition of a whistleblower in Section 2(a). The Act considers a whistleblower to be any natural person who in good faith reports information on antisocial activities to any relevant authority competent to receive such a report, including the Office and his or her employer. This means that the Act does not define a whistleblower as an employee only. Quite the contrary, the goal of the new Act is to provide adequate protection against any unlawful conduct or reprisal measure to the broadest possible spectrum of notifiers of anti-social activities. The definition provided by the Act therefore includes not only employees under employment relations (as legal relations established under both employment contracts and work agreements outside employment), but also civil servant employees and service employees, including temporary workers in all the mentioned forms of employment. Moreover, pursuant to the Act, the status of a whistleblower is also assigned to a person close to a whistleblower who works for the same employer as the whistleblower or for an employer directly dependent on the whistleblowers' employer or an employer established by the whistleblowers' employer.

Pursuant to the explanatory memorandum to the Act, a whistleblower is any person that found out about breaches or other anti-social activities in connection with his/her employment, function or status or public service. Therefore, the Act goes even further: since a whistleblower could literally be anyone that makes a report of anti-social activities to the relevant authority or body, the status of a whistleblower is granted also to persons employed on the basis of civil-law or commercial-law contracts, persons that are self-employed and independently provide services to their clients, as well as interns, trainees, volunteers or even members of statutory or other bodies in companies. In order to maintain the fullest effect of the statutory protection of whistleblowers, the term whistleblower is not (and should not be) subject to any future interpretative restrictions.

10 OJ EU L 305, 26/11/2019, pp. 17-56. 
The explanatory memorandum to the Act interprets the whistleblower as any natural person that found out about breaches or other anti-social activities in connection with his/her employment, function or status or public service. ${ }^{11}$ This should not mean that the reported anti-social activity must be somehow related only to the employment or function of the whistleblower. That would necessarily mean that the whistleblower could not possibly notify unlawful activities of his/her employer consisting of for example environmental damage or damage to the public health or corruption, if these unlawful activities did not occur in direct connection with the whistleblower's work or performance. This interpretation would certainly inappropriately limit whistleblower protection and is undoubtedly incoherent with the goal of the Act. This criterion should be, therefore, interpreted in a way that a whistleblower is any person that reported an antisocial activity that he or she found out about in connection with his or her employment, performance, status or function ${ }^{12}$.

Thanks to the new regulation that came with the Act, Section 7 of the Act states that once the status of whistleblower is granted, the employer may act against its whistleblower employee only if it proves that the proposed action has no causal link with the qualified notification. Otherwise, the employer needs the Office to consent to such an action. The employer has a burden of proof that the action has no connection with the qualified notification. If the employer cannot prove that, the Office will refuse its consent. ${ }^{13}$ Any act made by the employer against a whistleblower without prior consent of the Office is invalid.

Thanks to this new regulation, the Office was given an indeed strong competence to interfere with and intervene in sole-private-labour-law relationships justified by the necessity of whistleblower protection. Although the Office is still not properly established and functioning yet, we consider this particular aspect of ex ante protection to be probably the most effective way to secure a whistleblower's employment, since he or she is not forced to initiate a lawsuit in order to declare the invalidity of employment termination any more, which otherwise may have taken months or years before a satisfactory and definite conclusion was achieved. This kind of $e x$ ante protection may constitute much-needed motivation, since lack of motivation and fear of negative consequences are presented to be some of the most crucial reasons why people do not notify anti-social activities, even if they know of or find out about such breaches. ${ }^{14}$

11 See explanatory memorandum to Section 2 of the new Act. See also T. Mičudová, Zákon o ochrane oznamovatel'ov protispoločenskej činnosti. Komentár (Act on the protection of whistleblowers of anti-social activities Commentary to the Act), Wolters Kluwer, Bratislava 2019, pp. $16-17$.

12 See Nechala P., Chránené oznamovanie (whistleblowing), Inštitút pre verejné otázky (Act on the protection of whistleblowers of anti-social activities), Bratislava 2014, p. 107.

13 It is not possible to appeal against the decision of the Office.

14 See the report of Transparency International Slovensko, https://transparency.sk/sk/temy/ whistleblowing/, accessed 01/09/2021. 
On the other hand, the Act provides for special ex post protection against retaliatory measures already taken against a whistleblower. Pursuant to Section 12 of the Act, if the whistleblower considers that an act affecting their employment terms or working conditions with which he or she does not agree has been made in connection with the notification, he or she may request the Office to suspend the effectiveness of this act within 15 days from the day when the whistleblower became aware of the act. The Office immediately suspends the effects of the act affecting employment terms or working conditions if the time limit of 15 days has been complied with and the employer does not prove within a reasonable period determined by the Office that the act has in fact no causal connection with the notification.

It appears that between the two different means of ex ante and ex post protection, there might be a difference in the personal scope of the provisions. Whereas ex ante protection pursuant to Section 7 is limited solely to an employer-employee relationship, ${ }^{15}$ which we believe involves both kinds of relations, i.e. established by employment contracts as well as work agreements outside employment, ex post protection pursuant to Section 12 is drafted comparatively broadly.

Although in Section 12 of the Act, the terms "act affecting employment terms or working conditions" and "employer" are used, which might indicate that this ex post protection is focused solely on labour law relations just as Section 7, subparagraph 7 of Section 12, might indicate differently. Here, the Act states that the Office shall also immediately suspend the effectiveness of an act affecting employment terms or working conditions performed against a natural person who has disclosed facts about anti-social activities which he or she has learned about in connection with the performance of his or her employment, profession, position, function or public interest activity, if this natural person could legitimately believe that making the notification would not lead to a proper investigation of the notification or that making the notification could lead to a sanction. The provisions of subparagraphs 1 to 6 shall apply mutatis mutandis. Here one may consider whether the authors of the Act wished to broaden ex ante protection to cover only those employees that in fact have not made a notification by internal or external reporting channel, but who in fear of possible sanctions or inactivity of relevant authorities have gone public with the information about anti-social activity, or whether they wished to provide ex post protection also to persons cooperating with the wrongdoer based on civil-law or commercial-law contracts, or persons who are simply unpaid interns or volunteers.

Although one may think that the broad definition of a whistleblower should guarantee the same extent of protection on all levels of possible harms (including those in sole private-law sphere) to all notifiers of anti-social activities, the issue is rather more complex. It is easy to justify this level of protection by an external body, such as the Office, even in private-law relations, if the potentially harmed person is an employee which as a weaker party is benefiting from standard protective labour law regulations. However, when it comes to the self-employed, subcontractors working

15 See explicitly in the explanatory memorandum to Section 7. 
under civil-law or commercial-law contracts or members of statutory or other corporate bodies, the nature of these relationships is noticeably different. The contractual freedom including the free decision on who is going to be one's contractual partner may result in such a contractual agreement that any party, including the other contracting party as the future wrongdoer, may terminate the contract whenever they wish and based on whatever grounds parties have agreed to or even without any obligation to provide grounds for such termination. In sole private-law relationships where all parties to a contract have equal positions, the lack of a protective regulation is justifiable; in civil and commercial law, one may choose with whom and for how long he or she wants to be in a contractual relationship. More importantly, if he or she for some reason loses his or her trust in the other contracting party (regardless of the reason, let it even be a public notification of a wrongdoing), may he or she be forced to remain in such a relationship? For example, a member of a statutory body makes a public notification about a possible severe harm to the environment or to public health due to the company's business activities. Regardless of the benefits and positive impacts of such a notification, may the company be forced by the Office not to revoke such a member, even though there is no possibility that a whistleblower may continue to effectively perform his or her duties as a member of a statutory body? In other words, does Section 12 of the Act apply to whistleblowers that do not at the same time have the status of an employee/a worker?

We believe the answer to this question lies in the systematic approach to Section 12. Unlike Section 7 of the Act and the ex ante protection, which has a rather permanent effect (no negative act affecting employment terms or working conditions against a whistleblower may be made without the approval of the Office, otherwise it is invalid) and thus is indeed provided only to employees, ex post protection under Section 12 serves a very different purpose. The suspension of the effects of a negative act against a whistleblower (for example termination of a contract or removal from a position) by the Office is only temporary, i.e. it ends after 30 days after the delivery of the notification from the Office about the suspension, unless a motion for preliminary (emergency) ruling has been filed. In such a case, the duration of the suspension of the act's effect is extended until the court's decision on this motion becomes enforceable (Section 12 subparagraph 6 of the Act). Finally, the initiated proceedings lead to the main proceedings pursuant to antidiscrimination law. ${ }^{16}$

This means that Section 12 represents nothing more but a strengthening of the protection against severe discrimination behaviour sanctionable by the Anti-discrimination Act. Since the principle of equal treatment is fully applicable in the cases of reporting anti-social activity (see above), it may be concluded that Section 12, unlike Section 7 of the Act, is applicable to cases of whistleblowing even if the whistleblower is not an employee.

Due to the inapplicability of Section 7 outside the employer-employee relationship, the range of whistleblower protection guaranteed by the Act does not fully

16 See the explanatory memorandum to Section 12 of the Act. 
correspond with the broad definition of whistleblower, and the Office has no similar or other competence against potential reprisal measures (let us put aside Section 12, as it more or less acts only as a procedural remedy) if the whistleblower is not an employee, but has the status of an intern or a member of a statutory or another body, is self-employed or simply cooperates with the wrongdoer on the basis of a civil-law or a commercial-law contract. The remedies provided by the Anti-discrimination Act therefore might be considered as suitable means of protection, ${ }^{17}$ including invalidity of the discriminatory act, obligation to refrain from discriminatory conduct, satisfaction (even monetary, if justifiable) and claim for damages. ${ }^{18}$

\section{Material scope of whistleblower protection granted by the new Act}

The Act does not specify what is considered an anti-social activity for the purpose of whistleblower protection. However, the Act distinguishes between "anti-social activity" and "serious anti-social activity", to some extent also with regard the statutory consequences and level of protection of a whistleblower. Although there is no legal definition of anti-social activity, the Act thoroughly defines serious anti-social activity. By serious anti-social activity, the Act understands several particular criminal and administrative offences, i.e. (i) criminal offence of harming the financial interests of the European Union pursuant to Sections 261 to 263 of the Criminal Code,${ }^{19}$ criminal offence of machinations in public procurement and public auction pursuant to Sections 266 to 268 of the Criminal Code, criminal offences of public officials pursuant to Sections 326 to $327 \mathrm{a}$ of the Criminal Code, and criminal offences of corruption pursuant to Sections 328 to $336 \mathrm{~b}$ of the Criminal Code, (ii) an offence for which the Criminal Code provides for a prison sentence with a maximum duration of more than three years, (iii) an administrative offence for which a fine may be imposed with an upper limit determined by calculation, or (iv) an administrative offence punishable by a fine of at least EUR 30,000.

Precisely what is considered as anti-social activity is still not clear due to lack of case law, since the Act has not been implemented in practice yet. The doctrinal interpretation tends to be broad and may encompass all kinds of anti-social activities such as conflict of interest, abuse of power or authority, unprofessional conduct,

17 However, this approach sometimes evokes mixed reactions and concerns about an overly broad interpretation of discrimination. See J. Šamánek, (Ne)vhodnost zakotvení ochrany oznamovatelů v antidiskriminačním zákoně (The (in)appropriateness of enshrining whistleblower protection in anti-discrimination law), [in:] J. Pichrt, (ed.) Whistleblowing, Wolters Kluwer ČR, Prague 2013, pp. 46-52.

18 See Section 9 of the Anti-discrimination Act.

19 Act No. 300/2005 Coll. Criminal Code, as amended (hereinafter the "Criminal Code"). 
workplace bullying, clientelism etc. ${ }^{20}$ In this regard, a question may arise if also misdemeanours or minor employer's breaches in a workplace or breaches effecting only some, or even only one employee should be considered anti-social activity and thus be covered by the Act and if the whistleblower notifying of such minor breaches should be protected accordingly. As a matter of fact, the Act implicitly provides an answer.

The division into anti-social activity and serious anti-social activity is reflected in two kinds of whistleblower reports. If a whistleblower wants to report minor anti-social activity, he or she files a report. On the other hand, a qualified report is a report which may contribute or has already contributed to the clarification of serious anti-social activity or to the identification or conviction of a wrongdoer who committed of serious anti-social activity. The main difference between a report and a qualified report lies in the extent of the provided protection. A whistleblower may be granted a special kind of protection in on-going criminal or administrative proceedings only if he or she has filed a qualified report, i.e. he or she has reported serious anti-social activity. Moreover, it appears that the labour law protection pursuant to Section 7 of the Act is also provided only to a whistleblower filing a qualified report. This interpretation might be derived from the title of Section 7: "Protection of the whistleblower when reporting serious anti-social activity". Also financial incentives, which will be addressed below, are connected solely to the qualified report.

Although the Act defines the whistleblower remarkably broadly and we may indeed accept a broad interpretation of (ordinary) anti-social activity, the legislature managed to strip the whistleblower of almost all relevant protection, unless he or she reports serious anti-social activity. In all cases of reporting (basic, ordinary) anti-social activity, the whistleblower is left only with the protection given by the Anti-discrimination Act and logically by Section 12 of the Act as basically the only protective provision from the Act which applies in such cases.

We believe that this is an issue. Efforts to limit protection only to persons reporting criminal offences were already criticized in the past. ${ }^{21}$ Unfortunately, restricting material protection only to cases of reporting more severe criminal or administrative offences may not help with the existing lack of motivation to speak up without having to fear possible retaliatory measures. Leaving the protection of a whistleblower of less serious breaches to antidiscrimination remedies only while having a specialized Act regulation and the established specialized Office for the issue is rather unfortunate and we consider it a setback. The level of protection should not be dependent on the seriousness of the breach, and the issue is even more pressing if we take into account that the legislation continually fails to motivate people to come forward when finding out about miscellaneous unfair practices.

20 See T. Mičudová, Zákon o ochrane oznamovatel'ov protispoločenskej činnosti. Komentár (Act on the protection of whistleblowers of anti-social activities, Commentary to the Act), Wolters Kluwer, Bratislava 2019, p. 19.

21 See P. Nechala, Chránené oznamovanie (whistleblowing), Inštitút pre verejné otázky, Bratislava 2014, p. 109. 


\section{External and internal reporting}

Regarding the process of filing a report, the Act distinguishes between internal and external reporting. There is no priority between internal and external reporting. Thus, a whistleblower may request protection from a relevant authority (an external body) regardless whether he or she exploited an internal channel of communication through the company officer. The choice of communication channels is up to the decision of the whistleblower.

When it comes to filing a report, the new Act has brought a significant change. While the previous Act explicitly determined that the report may also be anonymous (Section 2(1d)(1.) of the previous Act), the Act does not recognize any more an anonymous report, which is interpreted in such a way that an anonymous report concerning any anti-social activity is not considered a whistleblower's report. ${ }^{22} \mathrm{We}$ believe that the logic behind the legislative change is in the perception of the purpose of the legislation, which is to grant adequate protection to a whistleblower against the potential harm of retaliatory measures from the wrongdoer. It is impossible to grant protection if we do not know the identity of the whistleblower.

Another question arises with regard to the anonymous report: has the relevant authority or an officer as a relevant body in the internal reporting channel the obligation to examine the facts provided in an anonymous report, and should an investigation be initiated in the case of reasonable concerns? We believe it is not correct to jump to the simplistic conclusion that if the Act essentially excludes an anonymous report from the material scope of whistleblowing regulation, this automatically means that the authorities have no further obligation to investigate. The subsequent regime after filing an anonymous report must be systematically coherent with other parts of the relevant regulation.

Pursuant to the Slovak Code of Criminal Procedure, ${ }^{23}$ if the content of an anonymous submission "does not give rise to a reasonable suspicion that a criminal offence has been committed", the prosecuting authority is not obliged to handle the anonymous report; if the contents indicate that the matter falls within the competence of another authority, the prosecuting authority forwards such an anonymous submission for examination of its contents to this other authority. Moreover, it is a criminal offence if one learns that another has committed a crime for which the Criminal Code provides for a prison sentence with a maximum duration of at least ten years or one of the corruption offences and does not report such a crime without delay to the relevant authority.

22 See T. Mičudová, Zákon o ochrane oznamovatel'ov protispoločenskej činnosti. Komentár (Act on the protection of whistleblowers of anti-social activities, Commentary to the Act), Bratislava 2019, p. 21.

23 The Act No. 301/2005 Coll. Code of Criminal Procedure as amended (hereinafter as "Code of Criminal Procedure"). 
In conclusion, it appears that although an anonymous report is not considered a whistleblower's report, if the Office or the company officer receive one and the facts provided suggest that a crime or an administrative offence was committed, the authorities competent for further investigation should be informed and provided with all the information obtained from the anonymous report.

\subsection{Internal reporting}

The current Act stipulates that certain types on employers are obliged to adopt an internal reporting system. The Act makes difference between private and public employers (i.e. the employer is a public authority) in that public employers have to meet stricter criteria for introducing an internal reporting system in comparison to private employers, i.e. different thresholds of the number of employees are applied: an employer who employs at least 50 employees and an employer who is a public authority employing at least five employees are obliged to designate a responsible person.

\subsubsection{Appointment of a "Responsible person" and internal rules}

The internal reporting scheme consist of an obligation to (i) appoint a responsible person and to (ii) issue an internal rule regulating the process of handling complaints.

a) Responsible person

Every employer with an obligation to issue and adopt an internal CSR standard also needs to appoint an organizational unit/branch or a person as an officer in charge (the Act uses the term "responsible person") of receiving reports, carrying out a verification process, informing whistleblowers about the outcome of the verification process and keeping records of all reports made (the records have to be kept for three years). Pursuant to the Act, the officer (= responsible person) needs to be "professionally capable" to duly perform all the obligations. However, the Act does not specify particular prerequisites the officer must meet. The responsible person does not have to be an employee of the employer or an organizational unit of the employer. The employer may also hire an external person to fulfil the functions of the responsible person. In municipalities and in regions with a local government, the responsible person is the chief controller (the appointment of such a person is obligatory under Slovak laws). In the case of fully state-owned entities or public entities established by a public institution, the founding public institution is obliged to perform the function of the responsible person if that entity employs fewer than 50 employees. However, the founding public institution may decide that it will perform the function of the responsible person also in the event that the entity established by it employs more than 50 employees.

The responsible person is bound only by instructions given by a statutory body. The employer is obliged to enable the responsible person to perform his/ 
her tasks independently, while the responsible person is bound only by the instructions of the statutory body of the employer or the statutory body of the parent company, unless the responsible person is directly a statutory body or a member of the statutory body. The employer is obliged to ensure that the tasks or responsibilities of the responsible person may not lead to a conflict of interests. The employer may not penalize or sanction the responsible person for carrying out his/her tasks. If the responsible person is an organizational unit, the employer cannot penalize or sanction the employees who work for that organizational unit. The employer is obliged to cooperate with the responsible person to the necessary extent in the performance of his/her tasks; in particular, the employer has to provide the responsible person with sufficient resources to carry out his/ her tasks and to access personal data and documents. Moreover, the employer has the obligation to continually maintain the professional qualifications of the responsible person.

The employer must clearly identify the responsible person, and the means of reporting must be published and accessible to all employees in the usual and commonly available way, so that at least one method of reporting must be accessible at all times. The employer has to make available information about the internal system for verifying notifications in a concise, comprehensible, clearly worded and easily accessible form.

b) Investigation of notifications

The employer is obliged to accept and verify each notification within 90 days of its receipt. This period may be extended by another 30 days. However, the employer must notify the notifier of the reasons for such extension. The employer is obliged to maintain the confidentiality of the identity of the notifier during the whole process of investigating the notification. The notifier has to be informed about the result of the investigation of the notification and about the measures, if any are taken on the basis of the investigation of the notification, within ten days of the investigation of the notification being completed. If the investigation of the notification is completed by transferring the case under the Criminal Procedure Code or under other special laws, the responsible person has to request the result of the investigation to the extent permitted by special laws and notify the notifier thereof within ten days of delivery.

c) Internal rule regulating whistleblowing - CSR standard

Employers who are obliged to appoint a responsible person (the same criteria are applied as described above with regard to the obligation to appoint a responsible person) likewise have to adopt an internal rule regulating whistleblowing. Such internal rule has to contain the details of the following issues:

i. submission of notifications,

ii. verification of notifications and authorizations of the responsible person in the investigation of notifications,

iii. maintaining confidentiality about the identity of the notifier, 
iv. registration of notifications and keeping records about the notification,

v. informing the notifier of the result of the investigation of his/her notification,

vi. processing of personal data referred to in the notification.

\subsubsection{Internal reporting and anonymous notifications}

Please note that the Act does not recognize anonymous notifications (unlike the previous Act, which explicitly determined that the notification may also be submitted anonymously). The fact that the Act does not recognize anonymous notifications any more is interpreted in such a way that an anonymous notification of any anti-social activity is not considered a whistleblower's report. ${ }^{24}$

This, however, does not automatically mean that an anonymous report under specific circumstances cannot be accepted as a criminal complaint. Hence, the prosecutor is obliged to initiate an investigation and eventually even criminal proceedings (for further details see above).

\subsubsection{Personal data protection and internal reporting}

Whistleblowing procedures must be a safe channel for notifications of important information relating to fraud, corruption or serious wrongdoings. This information is investigated in the course of a procedure involving the processing of personal data (for example, information relating to those suspected of wrongdoing as well that of the notifiers, other third parties, witnesses, etc.). The employer has to meet all requirements set forth by the GDPR ${ }^{25}$ and the national Slovak rules on personal data processing. ${ }^{26}$

Employers running whistleblowing schemes must ensure that all GDPR requirements are fulfilled. Confidentiality belongs to the most important elements of more than just supporting the notifiers in reporting any wrongdoings. It is also one of the most important requirements with regard to handling personal data. The data are very often sensitive personal data. It is therefore necessary to process the personal data and maintain utmost confidentiality. The employer must also process only the data that are important and not to process more personal data than necessary. Running the reporting scheme means that the employer must ensure an initial

24 See T. Mičudová, Zákon o ochrane oznamovatel'ov protispoločenskej činnosti. Komentár (Act on the protection of whistleblowers of anti-social activities, Commentary to the Act), Wolters Kluwer, Bratislava 2019, p. 21.

25 Regulation (EU) 2016/679 of the European Parliament and of the Council of 27 April 2016 on the protection of natural persons with regard to the processing of personal data and on the free movement of such data, and repealing Directive 95/46/EC (General Data Protection Regulation) (hereinafter "GDPR").

26 Act No. 18/2018 Coll. on personal data protection. 
verification of the reported information and must evaluate which information is relevant. The GDPR requires that the concerned persons have right to information, i.e. the employer must provide information through a general privacy notice, ${ }^{27}$ but also directly to the persons involved. These persons may include the whistleblowers, the person under investigation, witnesses or other individuals that are mentioned in the notification. However, the employer must consider carefully which information will be provided so that the investigation is not jeopardized. Generally, the concerned persons are entitled to have access to their personal data. It is necessary to keep a balance between the interests of all involved persons, including the notifier and the persons who are accused of wrongdoing. Personal data may not be processed for a longer period than is necessary or than is required by the law (according to Section 11(1) of the Act, records have to be kept for three years). In addition to fulfilling all administrative obligations, the employer must ensure the security of the processed personal data and adopt technical and organizational measures needed to eliminate the risks and to ensure personal data security.

The Office for Personal Data Protection has competence to enforce the compliance with personal data protection legislation including the obligation to maintain all required security measures and mechanisms to ensure the protection of the whistleblower's personal data. ${ }^{28}$ As has been mentioned above, details about data protection are a mandatory part of the internal rule regulating whistleblowing.

\subsubsection{Whistleblowing and anti-discrimination law}

As was already mentioned above, the Anti-discrimination Act enumerates the grounds on which discrimination is prohibited. According to the Slovak Anti-discrimination Act, the list of grounds is just enumerative and includes the ground of reporting a crime or other anti-social activity (Section 2(1) of the Anti-discrimination Act). In addition to the Anti-discrimination Act, the Slovak Labour Code (Act No. 300/2001 Coll.) does not contain a closed list of criteria in the case of discrimination.

The Anti-discrimination Act enumerates the criteria in the case of discrimination $^{29}$. "Whistleblowing" is not included explicitly among these criteria. If a person is discriminated against due to whistleblowing, it would be considered an unjustified sanction. The Anti-discrimination Act stipulates that an "unjustified sanction" (Section $2 \mathrm{a}(8)$ of the Anti-discrimination Act) is an act or omission which is unfavourable

27 The privacy notice must contain information specified under Article 13 of the GDPR.

28 See T. Mičudová, Zákon o ochrane oznamovatel'ov protispoločenskej činnosti. Komentár (Act on the protection of whistleblowers of anti-social activities, Commentary to the Act), Wolters Kluwer, Bratislava 2019, pp. 50-51.

29 See V. Križan, Antidiscrimination law (equality of treatment): introduction, [in:] V. Križan et al. (eds.), Implementation and enforcement of EU labour law in the Visegrad countries,, Palacký University, Olomouc 2014. 
and directly related to the person concerned and has direct connection with: (a) seeking legal protection against discrimination on his/her own behalf or on behalf of another person; or (b) giving a witness statement or explanation or participating in proceedings in matters related to the violation of the principle of equal treatment,

(c) making a complaint alleging a breach of the principle of equal treatment.

The application of anti-discrimination law brings some benefits to notifiers. The Anti-discrimination Act stipulates that the defendant is required to prove that he/ she has not infringed the principle of equal treatment if the plaintiff informs the court of facts from which it can reasonably be concluded that the principle of equal treatment has been infringed.

The whistleblower as an applicant is firstly required to identify in the application the person alleged to have infringed the principle of equal treatment. Furthermore, the whistleblower has to provide the facts he/she is aware of that prove the defendant breached the equal treatment principle. Based on these facts, the court may decide that the burden of proof is on the defendant.

The general three-year limitation period as stipulated by Section 101 of the Civil Code (Act No. 40/1964 Coll.) applies in employees' claims in discrimination cases. The period starts to run from the moment of the unjustified intervention that was objectively capable to violate the employee's right.

\subsection{External reporting}

There are several authorities with competence in external reporting channels. Firstly, the new established Office provides whistleblowers with labour-law protection pursuant to Section 7 and Section 12. Moreover, the Office has competence to award remuneration to a whistleblower that filed a qualified report (reported serious anti-social activity) amounting to up to 50 times the minimum wage. When examining an application for remuneration, the Office takes into account the extent of the whistleblower's participation in clarifying serious anti-social activity and identifying the perpetrator, the whistleblower's lost earnings and the extent of the seized or returned property, if quantifiable. To that end, the Office seeks the opinion of the prosecutor or administrative authority which has acted in the matter. A whistleblower has no claim on remuneration, as it is solely in the Office's discretion if and to what extent a whistleblower is granted remuneration.

Awarding a whistleblower a monetary reward is generally an issue of controversy. However, the legislature justifies it with the argument that the whistleblower's help to preserve protected property or to return property are a significant benefit to public interest. ${ }^{30}$ Although this regulation has not yet been fully brought to life as there is only one case presented by the Ministry of Justice when a whistleblower received a remuneration and consequently we have no data to study if granting

30 See the explanatory memorandum to Section 9 of the Act. 
remuneration has a motivational effect on future whistleblowers, we consider it to be some kind of a social experiment that may possibly have a positive impact on raising the awareness of the whistleblower regulation and motivating people to come forward. We are of the opinion that this is probably the only place where distinguishing between reporting anti-social activity and serious anti-social activity may be reasonably justified.

When it comes to protection in criminal or administrative proceedings, a whistleblower may request protection from the relevant criminal or administrative body that investigates the case. After filing a request, the whistleblower is automatically granted labour-law protection provided by the Office. Moreover, in criminal proceedings, the court may decide that the identity of the whistleblower as a witness will not be disclosed. The court may decide not to provide personal information of the witness only if there is a reasonable concern that disclosing the witness's identity, residence or whereabouts may endanger his/her life, health or physical integrity or that such a danger is imminent to a person close to him/her.

\section{Conclusions}

After analysing the basic elements of the new whistleblowing regulation, it seems that although the new Act defines the whistleblower indeed very broadly, material protection pursuant to the new Act is provided only to whistleblowers reporting serious anti-social activities, i.e. more severe criminal or administrative offences. Furthermore, protection against acts with a negative impact on the whistleblower's position in the workplace is provided virtually only to employees, while other persons (volunteers, interns, self-employed etc.) are left with only remedies provided by the Anti-discrimination Act. Thus, it can be concluded that the new Act is actually not very progressive when compared with the previous legislation, and that the legislature clearly missed an opportunity to protect all types of whistleblowers in the same way by the same specialized Office established solely for the protection of whistleblowers.

To summarize the whistleblowing legislation in the Slovak Republic, it must be stressed that the legislation is not applied very often. Both the previous Act and the current Act require some employers to introduce whistleblowing reporting schemes. In our research, we also made an inspection of Internet sites of employers that are obliged to introduce a whistleblowing reporting system. Generally, public institutions are well aware of their obligation to introduce internal reporting and provide information about submitting and handling notifications on their websites. Private employers usually use internal channels to inform their employees about internal reporting.

The most serious shortcoming in the application of the Slovak whistleblowing legislation is that the Office for Whistleblower Protection has been fully established 
only in September 2021 as the chairperson of this office was elected by the Slovak Parliament only months earlier, in February 2021. The functions of the Office were until now performed by the Labour Inspectorate. However, the latest announcement about whistleblowing available on the Labour Inspectorate's website is from March 2019 and contains information about the passing of the Act. ${ }^{31}$ However, we expect that the application of whistleblowing reporting will be more frequent after the transposition of the Directive 2019/1937 of the European Parliament and of the Council of 23 October 2019 on the protection of persons who report breaches of Union law and after establishing the Office for Whistleblower Protection.

\section{Abstract}

In this chapter, the authors try to analyse the main aspects of the new Slovak Act on whistleblower protection No. 54/2019 Coll. Firstly, the authors highlight the fact that although Slovakia has a specialized Act regulating whistleblowing, other applicable legislation exists, as well. As it turns out, the antidiscrimination legislation still plays an important role, as the new Slovak Act does not cover all cases of whistleblowing protection. Furthermore, the authors analyse the personal and material scope of the provided protection and contemplate the connection between the definition of the whistleblower and the protection provided pursuant to the new Act. With regards to the material scope of protection, the act distinguishes between two kinds of anti-social activities depending on their severity. As it turns out, protection pursuant the new Act is provided only to whistleblowers reporting more serious anti-social activities. In other cases, the antidiscrimination legislation is the only platform for protection of such notifiers. Lastly, the new Act establishes both internal and external channels for reporting anti-social activities, with the new established Office for the Protection of Whistleblowers playing an important role. Although the Office is more or less only an administrative and monitoring body, it also grants specialized ex ante and ex post protection directly in labour law employer-employee relations and closely cooperates with relevant authorities competent for investigating criminal or administrative offences.

\section{Bibliography}

Barancová H. a kol., Zákonník práce. Komentár (Labour Code. Commentary), 2. edition, C. H. Beck, Bratislava 2019.

Debréceniová J., Antidiskriminačný zákon. Komentár. Občan a demokracia (Anti-discrimination law. Commentary. Citizen and Democracy), Bratislava 2008.

31 https://www.ip.gov.sk/prostispolocenska-cinnost/?ip=nip, accessed 01/09/2021. 
Križan V., Antidiscrimination law (equality of treatment): introduction, [in:] V. Križan et al. (eds.), Implementation and enforcement of EU labour law in the Visegrad countries,, Palacký University, Olomouc 2014.

Nechala P., Chránené oznamovanie (whistleblowing), Inštitút pre verejné otázky, Bratislava 2014.

Mičudová T., Zákon o oznamovaní protispoločenskej činnosti.Komentár (Act on reporting anti-social activities. Commentary). Wolters Kluwer, Bratislava 2016.

Mičudová T., Zákon o ochrane oznamovatelov protispoločenskej činnosti. Komentár (Act on the protection of whistleblowers of anti-social activities. Commentary to the Act), Wolters Kluwer, Bratislava 2019.

Olšovská A., Hrušovská V., Whistleblowing na pracovisku - právna úprava, teória a prax na Slovensku Whistleblowing at the workplace - legislation, theory and practice in Slovakia, [in:] J. Pichrt (ed.) Whistleblowing, Wolters Kluwer ČR, Prague 2013.

Pichrt J. (ed.), Whistleblowing, Wolters Kluwer ČR, Prague 2013.

Šamánek J., (Ne)vhodnost zakotvení ochrany oznamovatelư $v$ antidiskriminačním zákoně (The (in)appropriateness of enshrining whistleblower protection in anti-discrimination law), [in:] J. Pichrt, (ed.) Whistleblowing, Wolters Kluwer ČR, Prague 2013. 